\title{
35. PRESENT AND PAST TEMPERATURES OF SEDIMENTS AT SITE 857, MIDDLE VALLEY, NORTHERN JUAN DE FUCA RIDGE ${ }^{1}$
}

\author{
Earl E. Davis² and Kelin Wang ${ }^{2}$
}

\begin{abstract}
Ocean Drilling Program Hole 857D, located within the sediment-filled Middle Valley rift of the northern Juan de Fuca Ridge, was drilled through a $470-\mathrm{m}$ section of turbidites and into a series of basaltic sills interbedded with sediments. Accurate temperature measurements in this hole are limited to the upper $80 \mathrm{~m}$ of the sediment section. We have estimated temperatures at greater depths using these constraints, and physical properties derived from shipboard and shore-based measurements. Temperature estimated in this way is found to reach $280^{\circ} \mathrm{C}$, the maximum temperature of vents at Site 858 roughly $2 \mathrm{~km}$ away, at a depth that coincides with the top of the first sill. This coincidence is consistent with the hypothesis that the section of interbedded sills and sediments forms a permeable hydrothermal reservoir in which convective heat transport is highly efficient, and is overlain by a relatively low-permeability sediment section where heat transport is conductive. To estimate the thermal history of the sediment section, we have applied a model of sedimentation on a boundary that is maintained at a constant temperature. The history of late Pleistocene sediment accumulation was inferred from a variety of simple constraints including the local seismic structure, variations in core lithology, biostratigraphic markers, and limits on the local crustal age based on the position of the site relative to the rift axis. Limits on the timing of sill emplacement are provided by stratigraphic correlations between Sites 857 and 858 . With these constraints, model results show that sediment at all levels has warmed throughout the history of deposition, although the section has probably been at close to its current thermal structure for most of the past $125,000 \mathrm{yr}$, during a period of relatively slow sediment accumulation. This conclusion agrees with the observed levels of hydrocarbon maturation and with the isotopic composition of authigenic minerals in the section.
\end{abstract}

\section{INTRODUCTION}

Drilling at Ocean Drilling Program (ODP) Site 857 on the northern Juan de Fuca Ridge was directed at penetrating the relatively impermeable sediment fill of the Middle Valley rift into what was suspected to be a regional hydrothermal "reservoir" in the upper igneous crust (Davis and Villinger, 1992). This reservoir was inferred to contain hightemperature fluids that chemically interact with their permeable host rocks, and to supply water to remote areas of focused discharge. Many of the scientific goals at this site were realized. In particular, the concept of a basement hydrothermal "reservoir" was found to be generally correct. The 936-m Hole $857 \mathrm{D}$ penetrates through a 470 -m-thick sequence of semi-indurated upper Pleistocene turbidites into a thick sequence of basaltic sills interbedded with sediments (Shipboard Scientific Party, 1992b). Packer experiments (Shipboard Scientific Party, $1992 \mathrm{~b}$; Becker et al., this volume) showed this sequence to be highly permeable on average. Fluid flow is probably dominated by the presence of two or three highly permeable zones, probably faults (Langseth and Becker, this volume). Permeability of the section excluding these zones is considerably lower, about $2 \times 10^{-14} \mathrm{~m}^{2}$, although still sufficient to allow porous-medium hydrothermal convection (Bessler et al., this volume). Composition of the sediment below the level of the shallowest intrusion shows that many mobile elements have been completely removed by fluid circulation, supporting the notion of generally pervasive permeability. Above this level, sediment and pore-fluid compositions (Shipboard Scientific Party, 1992b) and permeability measurements on core samples (Fisher et al., this volume) show that the sediment section serves as an effective barrier to vertical fluid flow.

Unfortunately, some of the goals for the program were not fully realized. In particular, accurate measurements of temperature were limited to those made during drilling with the advanced piston corer (APC) and the water sampling temperature probe (WSTP) in the

\footnotetext{
${ }^{1}$ Mottl, M.J., Davis, E.E., Fisher, A.T., and Slack, J.F. (Eds.), 1994. Proc. ODP, Sci. Results, 139: College Station, TX (Ocean Drilling Program).

${ }^{2}$ Pacific Geoscience Centre, Geological Survey of Canada, P.O. Box 6000, Sidney, British Columbia V8L 4B2, Canada.
}

upper $80 \mathrm{~m}$ of the section only (Shipboard Scientific Party, 1992b). Measurements made deeper in the section either during (Shipboard Scientific Party, 1992b; Langseth and Becker, this volume) or after the drilling leg (Davis et al., 1992; Davis and Becker, this volume) were severely affected by drilling circulation and by strong downhole flow, and by penetration of seawater into permeable parts of the formation forced by the large density contrast between the cold seawater in the hole and the hot water filling pores and fractures of the undisturbed formation.

In this paper, we have attempted to improve the estimates of present-day formation temperatures at depth by combining the best temperature measurements made during drilling with estimates of in-situ physical properties derived from shipboard and shore-based laboratory analyses. We also have speculated on the thermal history of the sediment that has been deposited on top of the hydrothermal basement. The results of the thermal history model we have applied provides a context in which the alteration of the sediments can be better understood, in particular the maturation and possible migration of hydrocarbon compounds, the inorganic chemical interaction of sediments and pore fluids, the thermal diagenesis of clays and other minerals, and the isotopic composition of recrystallized minerals.

\section{ESTIMATED PHYSICAL PROPERTIES AND PRESENT-DAY TEMPERATURE PROFILE}

An estimate of the present and past thermal structure of the sediment section at Site 857 requires an estimate of the physical properties of the sediment section; an estimate of the past thermal structure also requires a knowledge of the local sedimentation history. The former is discussed here, and the latter in the next section. We have assumed that the porosity-depth profile has been constant with time, following a simple relationship with depth of the form

$$
\phi=\phi_{0} e^{-\frac{z}{L}}
$$

Values of the porosity at the seafloor $\phi o=70 \%$, and of the depth-scale of porosity change $\mathrm{L}=495 \mathrm{~m}$, result from a regression fit of this 


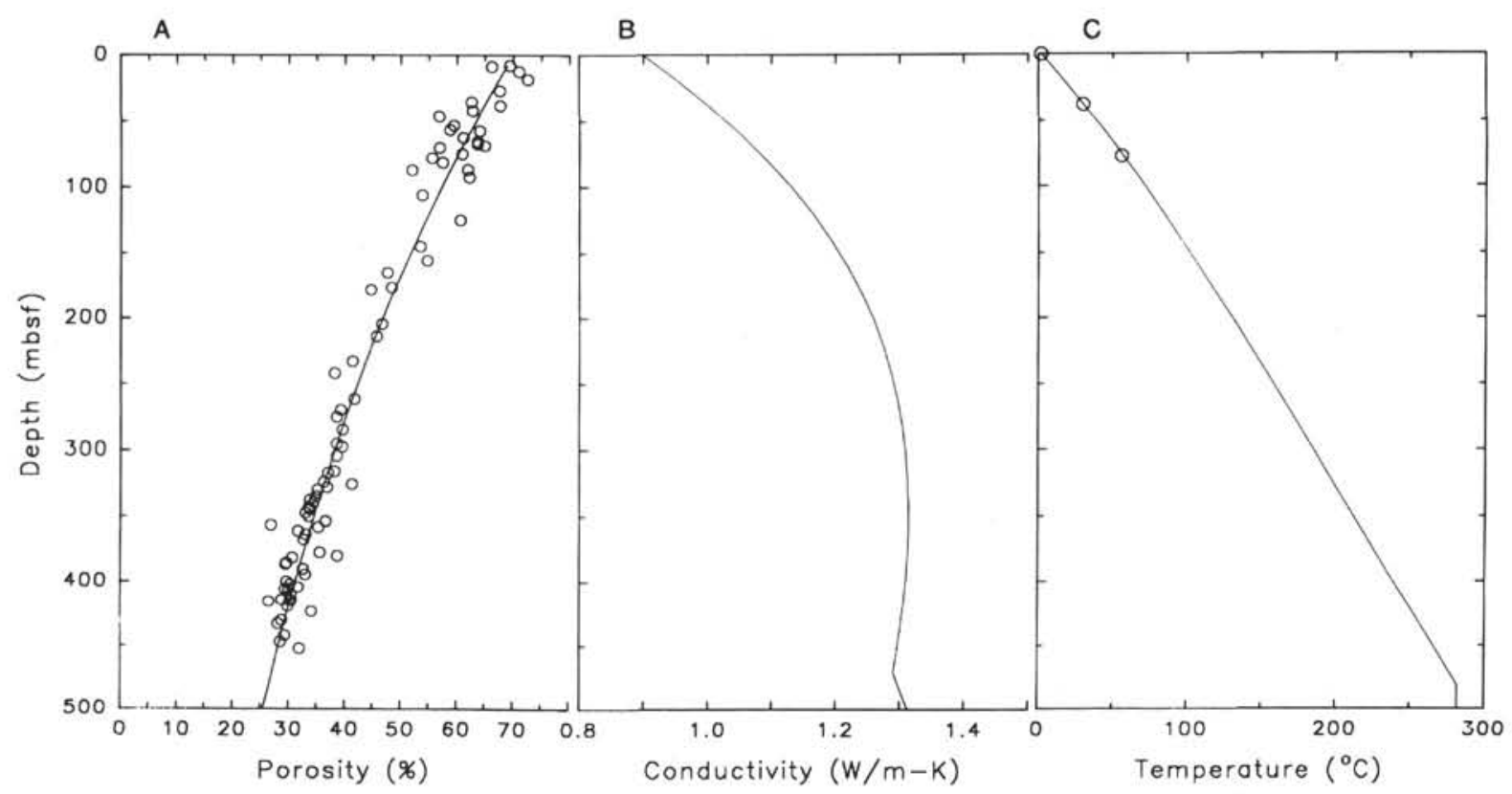

Figure 1. Plots of porosity (A), thermal conductivity (B), and temperature (C) as functions of depth below seafloor for Hole 857D. Shipboard porosity data (Shipboard Scientific Party, 1992b) are shown together with the exponential function $\phi=\phi_{o} \exp (-z / 495)$. The conductivity profile was estimated using a geometric mean mixing relationship and the porosity profile shown in Figure 1A. Conductivities of the constituents were corrected for the effects of temperature using the relationships shown in Figure 2. The temperature profile was determined using WSTP temperature observations made during drilling (open circles) (Shipboard Scientific Party, 1992b) and the thermal conductivity profile shown in Figure 1B.

exponential function to shipboard porosity data (Shipboard Scientific Party, 1992b) (Fig. 1A).

Thermal conductivity (Fig. 1B) has been determined using a geometric mean mixing relationship (e.g., Brigaud and Vasseur, 1989) and an estimate of the conductivity of the fluid and solid constituents, in a manner similar to that of Villinger et al. (this volume). For this study we have used a grain conductivity value of $2.6 \mathrm{~W} / \mathrm{m}-\mathrm{K}$ as determined from the relationship between porosity and thermal conductivity measured along the vertical axis of samples with a divided bar (Davis and Seemann, this volume). This value differs significantly from the value of $3.12 \mathrm{~W} / \mathrm{m}-\mathrm{K}$ determined from shipboard measurements (Shipboard Scientific Party, 1992b). This is because the lower-porosity sediments possess large anisotropy; shipboard measurements were representative of the horizontal component, which was determined to be $20 \%$ higher than the vertical component.

The effect of temperature on the conductivity of both the grains and pore water was included using the relationships shown in Figure 2 , and an iterative estimate of the temperature-depth profile through the sediment section. The effect of temperature was not included directly in the thermal history models described in a following section; this complexity was not justified because the difference between the conductivity at the initially estimated temperature and that at the final temperature was small. The dependence of the thermal conductivity of water $\lambda_{\mathrm{w}}(\mathrm{W} / \mathrm{m}-\mathrm{K})$ on temperature $\mathrm{T}\left({ }^{\circ} \mathrm{C}\right)$ was derived from data of Sengers and Watson (1987). For the range of $0^{\circ} \mathrm{C}$ to $300^{\circ} \mathrm{C}$, this can be expressed as a polynomial:

$$
\lambda_{w}=0.688-1.57 \times 10^{-4} \theta-5.98 \times 10^{-6} \theta^{2}+4.1 \times 10^{-9} \theta^{3},
$$

where $\theta=T-150^{\circ} \mathrm{C}$. The temperature dependence of the sediment grain conductivity is taken to be the same as that of acid rocks summarized by Zoth and Haenel (1988), and follows the relationship.

$$
\lambda_{s}=0.595+\frac{750}{350+T} .
$$

The final profile of thermal conductivity is shown in Figure 1B, and the steady-state temperature profile, estimated by extrapolating the gradient defined by water sampling temperature-probe (WSTP) measurements made in the upper $80 \mathrm{~m}$ of the section in Hole 857D (Shipboard Scientific Party, 1992b), is shown in Figure 1C. The effects of temperature and anisotropy are seen to reduce substantially the thermal conductivity at depth, and cause the thermal gradient to be higher than that estimated without considering these effects (Shipboard Scientific Party, 1992b).

That the calculated temperature profile intersects $280^{\circ} \mathrm{C}$ at a depth of approximately 470 meters below seafloor (mbsf) is probably significant. This temperature is virtually identical to the maximum measured temperature of water venting at the Site 858 vent field roughly $2 \mathrm{~km}$ away (Shipboard Scientific Party, 1992c). The depth coincides with the depth of the shallowest intrusive rocks, the depth at which the sediment becomes highly altered and is stripped of many mobile elements (Shipboard Scientific Party, 1992b), and thus by inference the depth at which significant permeability is present. With sufficiently high basement permeability, it is expected that the reservoir and vent temperatures should be nearly the same (Bessler et al., this volume). For this reason, $280^{\circ} \mathrm{C}$ is used for the hydrothermal reservoir temperature, and $470 \mathrm{mbsf}$ the depth of the reservoir, in the transient thermal modelling described in a following section. Obviously, there is some uncertainty about how constant the temperature has been through time. Hydrothermal temperatures may have been lower or possibly as high as $400^{\circ} \mathrm{C}$ in the past. Geochemical or mineralogical observations may help to set limits on the variability.

\section{CONSTRAINTS ON THE HISTORY OF SEDIMENTATION}

Information about the history of sedimentation can be derived from the local sediment structure as defined by seismic-reflection data, from the sediment lithology sampled during drilling, and from biostratigraphic data. We have assumed that sedimentation has been 


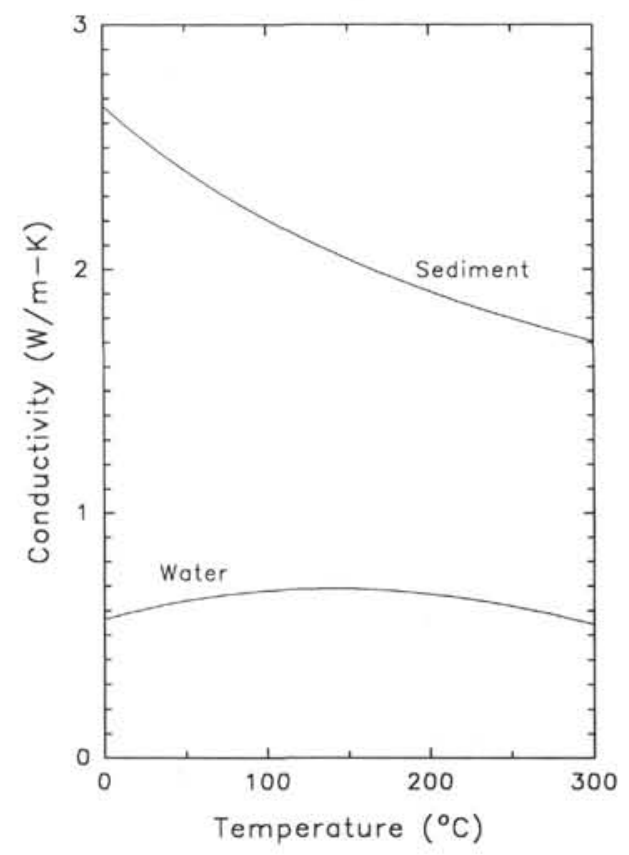

Figure 2. Values of thermal conductivity as functions of temperature for seawater and sediment grains used to estimate the in-situ sediment thermal conductivity as a function of depth (Fig. 1B) from the porosity and temperature profiles given in Figures $1 \mathrm{~A}$ and $1 \mathrm{C}$.

controlled structurally by the subsidence of the axial valley, with faster subsidence giving rise to faster accumulation. Sediment supply during the Pleistocene is assumed to have been always sufficient to keep the basin filled to the regional base-level of turbidite sedimentation (see Davis and Villinger, 1992). A portion of a seismic-reflection profile crossing the Middle Valley rift near Site 857 is shown in Figure 3 . The site is located about $7 \mathrm{~km}$ east of the rift axis, near the crest of a fault block that has been uplifted relative to the level of sediment deposition on the axial valley floor. Interpretation of the seismic structure suggests a geologic history in which sediment accumulated in a central rift environment to form a thick sequence of parallel-bedded reflectors (unit C in Fig. 3),

At some stage this sequence was intruded by the sequence of sills that now lies below 470 mbsf. The emplacement of most of the sills probably took place early in the depositional history, because there is a sequence of turbidite layers imaged by electrical resistivity logging at Site 857 that is slightly deeper than a correlative sequence at Site 858 (Langseth and Becker, this volume). The sediment section at the latter site was deposited on an extrusive volcanic edifice, and it is unlikely that it could have been affected (uplifted) by sill intrusion. That the sequence at Site 857 is deeper (possibly because of compaction of the deeper sediments), not shallower than its equivalent at Site 858 , strongly suggests that the sills were intruded before this part of the section (currently above $275 \mathrm{mbsf}$ ) was deposited.

At some later time, the sill sequence and overlying sediment section began to be tilted and uplifted relative to the central part of the rift, so that a sequence of fanned reflectors was produced (unit B, Fig. 3). The seafloor along the westernmost $3 \mathrm{~km}$ of the fault block is now well above the local base-level of turbidite deposition, by up to $50 \mathrm{~m}$. A thin sequence of flat-lying post-uplift reflectors onlaps the tilted sequences just beyond the eastern end of the profile.

This history is consistent with that suggested by the general lithology at Site 857 . The turbidites change in character at a depth of about 27 mbsf (Shipboard Scientific Party, 1992b). The uppermost part of the section comprises intervals of mud typically a few tens of centimeters thick, separated by layers of coarse turbiditic silt that are typically less than $1 \mathrm{~cm}$ thick (lithologic Unit I; Shipboard Scientific
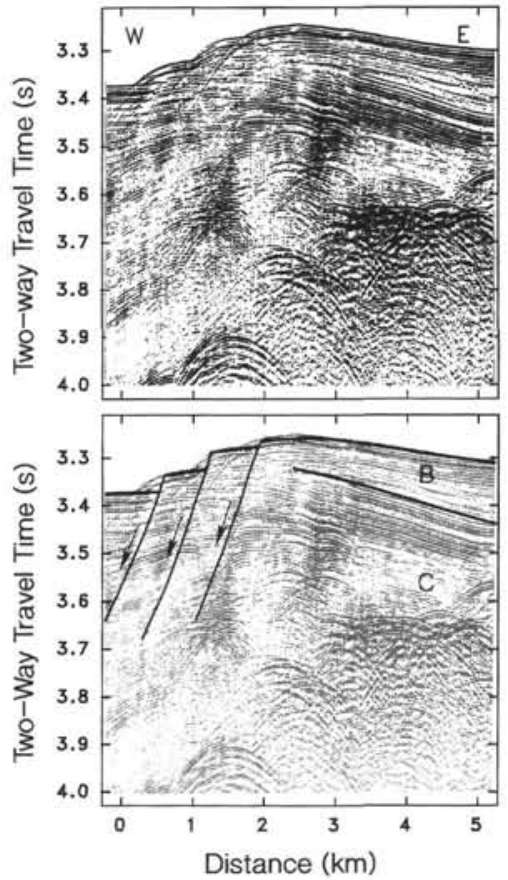

Figure 3. Single-channel seismic-reflection profile across the fault block into which the holes at Site 857 were drilled. The simple interpretation outlines two of the units described in the text. Site 857 , located about $3 \mathrm{~km}$ south of the line, lies at a position equivalent to roughly $3 \mathrm{~km}$ along the line.

Party, 1992b). Below this depth (Section 139-857A-4H-3), the thicknesses of the coarse turbiditic layers become distinctly greater, commonly exceeding $10 \mathrm{~cm}$, and the mean grain size increases to silty sand (lithologic Unit II; Shipboard Scientific Party, 1992b). Some sandy layers are particularly thick and massive; one layer that was imaged well with magnetic susceptibility is over $1.5 \mathrm{~m}$ thick (Sections 139-857A-10H-5 and -6). This lithology persists to the bottom of the hole. We infer that the change at $27 \mathrm{mbsf}$ is a result of the uplift of the fault block (Fig. 3) and marks a change in the local accumulation rate.

Age constraints in the section are limited, but fortuitously distributed. Three biostratigraphic ages of 10,73 , and 125 ka were determined at depths of approximately 1,17 , and $27 \mathrm{mbsf}$, respectively (Shipboard Scientific Party, 1992b); the oldest of these lies close to the depth at which the coarse turbidite layers become thicker. The earliest and latest dates have been confirmed by Brunner (this volume) and are used here as constraints on the sediment accumulation history. Accumulation rates for the interval above $27 \mathrm{mbsf}$ range from 0.1 to $0.25 \mathrm{~mm} / \mathrm{yr}$, with accumulation slowest during the Holocene. In the modelling described in the next section, we use the average value of $0.22 \mathrm{~mm} / \mathrm{yr}$ as the constant subsidence rate for the accumulation of the $27 \mathrm{~m}$ of sediment from $125 \mathrm{ka}$ to the present.

The history of accumulation prior to $125 \mathrm{ka}$ is not well constrained, because there are no age determinations in the sediment below $27 \mathrm{mbsf}$, and because the total thickness of sediment is unknown; Hole 857D bottomed at 936 mbsf in a sequence of mafic sills interbedded with sediments with no indication of a volumetric increase of the igneous component. An approximate lower limit for the accumulation rate for the deeper part of the section can be derived from the total thickness of sediment drilled (roughly $750 \mathrm{~m}$ ) and the approximate age of this part of the rift valley (roughly $250 \mathrm{ka}$ ) derived from its position relative to the rift axis and an assumption that the recent spreading rate has been equivalent to that during the Brunhes magnetic epoch (Davis and Villinger, 1992; Shipboard Scientific Party, 1992b). Accumulation at an average rate of $6 \mathrm{~mm} / \mathrm{yr}$ is implied for this deeper part of the section. 


\section{ESTIMATED THERMAL HISTORY}

Geothermal heat is absorbed by sediment accumulating on the seafloor; the effects of sedimentation can be thermally significant if the rate and duration of accumulation are sufficiently great (e.g., Von Herzen and Uyeda, 1963; Hutchison, 1985). Wang and Davis (1992) presented a model for computing the thermal effects of sedimentation for the specific case in which cold sediments are deposited on a surface that is maintained at a constant temperature. This model was developed to simulate conditions in active marine hydrothermal environments, where heat is supplied to the base of accumulating sediment sections by hydrothermal convection. This model is felt to be most appropriate for the study of the sediment thermal history at Site 857 in the Middle Valley rift in light of the inferences and assumptions outlined earlier.

In the model of Wang and Davis (1992), the sediment surface is fixed at a depth of $z=0$, and the basement, maintained at a constant temperature, moves downward. This model is similar to that of Hutchison (1985) in that compaction is assumed to maintain a constant porosity-depth profile, and the velocities of sediment particles and of expelled pore-fluid are calculated from conservation of mass using this porosity profile. It is assumed that fluid migrates upwards through the sediment section; none escapes across the lower boundary.

It is easily observed that for any depth $z$ and time $t$,

$$
v_{s}(z, t)[1-\phi(z)]=v_{b}(t)[1-\phi(B)],
$$

and

$$
v_{w}(z, t) \phi(z)=v_{b}(t) \phi(B),
$$

where $\phi$ is porosity, $v$ represents velocity, and subscripts $s, w$, and $b$ denote sediment, water, and basement, respectively. $B$ is the depth of the basement. Sediment and water velocities are readily determined using equations (4) and (5) from the specified basal subsidence rate $v \mathrm{~b}$. The temperature in the sediment section is determined from the heat transfer equation

$$
\overline{\rho c} \frac{\delta T}{\delta t}=\frac{\delta}{\delta z} \bar{\lambda} \frac{\delta T}{\delta z}-\overline{\rho c v} \frac{\delta T}{\delta z}+Q,
$$

where $\rho c$ is the volumetric thermal capacity (density and specific heat), $\lambda$ is thermal conductivity, and $Q$ is heat generation; a bar at the top denotes the average property of the matrix and pore fluid mixture. For sediment,

$$
\begin{gathered}
\overline{\rho c}=\rho c_{w} \phi+\rho c_{s}(1-\phi), \\
\overline{\rho c v}=\rho c_{w} v_{w} \phi+\rho c_{s} v_{s}(1-\phi)=v_{b} \overline{\rho c}(B),
\end{gathered}
$$

and the average conductivity is given as a function of $\lambda_{w}, \lambda_{s}$, and $\phi$, as discussed previously. We assume constant values of $\rho c_{w}$ of 4.3 $\mathrm{MJ} / \mathrm{m}^{3}-\mathrm{K}$ and $\rho c_{s}$ of $2.65 \mathrm{MJ} / \mathrm{m}^{3}-\mathrm{K}$ (Wang and Davis, 1992).

Equation (6), subject to the boundary conditions of specified temperatures at $\mathrm{z}=0$ and $z=B$, is solved numerically with a one-dimensional finite element method. Some complication arises because the model has a moving lower boundary. This problem is resolved both by allowing the grid to deform and by adding new elements to the bottom of the model when necessary, so that the growth of the sediment layer can be accurately modelled. Details of this approach are given in Wang and Davis (1992).

Four different cases are considered in the transient thermal modelling. In all cases, sedimentation follows the history discussed previously, with the uppermost $27 \mathrm{~m}$ of the section being deposited from $125 \mathrm{ka}$ to the present; the material below that is assumed to have been deposited during the period from 250 to $125 \mathrm{ka}$. To examine the consequences of hydrothermal circulation in basement, we have con- sidered the situation described earlier in which sediment accumulates on a surface that is held at constant temperature through time (referred to as the hydrothermal basement, or HB- cases). For comparison, we also have considered the situation in which the cooling of the basement is by pure conduction (referred to as the conductive basement, or CB- cases). In the latter, basement has been assigned a thermal conductivity of $2.9 \mathrm{~W} / \mathrm{m}-\mathrm{K}$ and volumetric thermal capacity of 3.86 $\mathrm{MJ} / \mathrm{m}^{3}-\mathrm{K}$.

Because of the large uncertainties in the timing of the intrusion of the sills below $470 \mathrm{mbsf}$, we have considered two cases in each of the two (CB and $\mathrm{HB}$ ) situations. In cases CB-1 and HB-1, the basement that is presently at $470 \mathrm{mbsf}$ was already formed at the beginning of sedimentation ( $250 \mathrm{ka})$; this is to approximate the assumption that the sills were intruded early in the history of this part of the rift and that a shallow basement had developed prior to most of the sedimentation. In cases CB-2 and HB-2, the first period of sedimentation is assumed to have taken place on a basement that now lies at a depth of about $1000 \mathrm{mbsf}$ (arbitrarily placed just below the bottom of Hole 857D; the exact depth is of little importance). Deposition proceeded through the $250-125 \mathrm{ka}$ time period to produce the section that is now below 27 mbsf. It was assumed that emplacement of the sills was contemporary with the change of sedimentation rate, with a new level of basement established at a depth that eventually would be at the present depth of 470 mbsf. The times assumed were chosen to bracket all reasonable possibilities; the earliest time of emplacement was used in case 1, and the latest (perhaps somewhat later than reasonable as discussed previously) in case 2 .

Several simplifying assumptions were made about the nature of basement in both the hydrothermal and conductive basement cases. In the former, it was assumed that high permeability develops and hydrothermal temperatures are established immediately upon sill emplacement. For example, in case HB-2, upon the intrusion of sills at $125 \mathrm{ka}$, the section representing the new basement (what is below 470 mbsf presently) suddenly became isothermal at a constant temperature of $280^{\circ} \mathrm{C}$. This is bound to be incorrect at some scale, although on scales greater than tens of meters or tens of years, the assumption is probably valid. In the conductive basement cases, deposition takes place on a half-space that cools conductively from an initial uniform temperature of $1200^{\circ} \mathrm{C}$. For example, in case CB-2, upon the intrusion of sills at $125 \mathrm{ka}$, the section representing the new basement (what is now below $470 \mathrm{mbsf}$ ) suddenly became $1200^{\circ} \mathrm{C}$ throughout, and gradually cooled down from the top by heat conduction. The heat content of the sills is modelled in a crude manner. In the simulation, the volume of the sills occupies the entire thickness of the section below 470 mbsf, whereas in reality, more than $50 \%$ of the section comprises sediment interbeds. Errors associated with this simplifying assumption are closely offset by those of another, however; latent heat of crystallization has been ignored.

Model results are presented in Figures 4 (for CB) and 5 (for $\mathrm{HB}$ ), where the temperature-time histories at discrete depths are shown in two reference frames. Dashed lines track temperatures at depths that are fixed relative to the seafloor. Of more interest in terms of diagenesis, hydrocarbon maturation, and geochemistry are the solid lines that track temperatures of individual sediment elements that are now at specific depths (indicated by the numbers at the tails of the solid curves).

All of the model simulations yield solutions for present-day temperatures that are remarkably close to the estimated temperature profile for Site 857 shown in Figure 1C. In the cases of the conductive models (Fig. 4), adjustments well within the uncertainties of the age controls could be made to the specified depositional histories to produce perfect matches. Therefore, on the basis of the current thermal regime of the section above $470 \mathrm{mbsf}$, the situation involving purely conductive heat transport cannot be excluded. However, on the basis of the thermal history of the sediment section, case CB-2 (Fig. 4B) can be rejected because the high temperatures that are predicted to develop between 470 and about 300 mbsf soon after sill emplacement are not supported by any geochemical and fluid inclusion obser- 

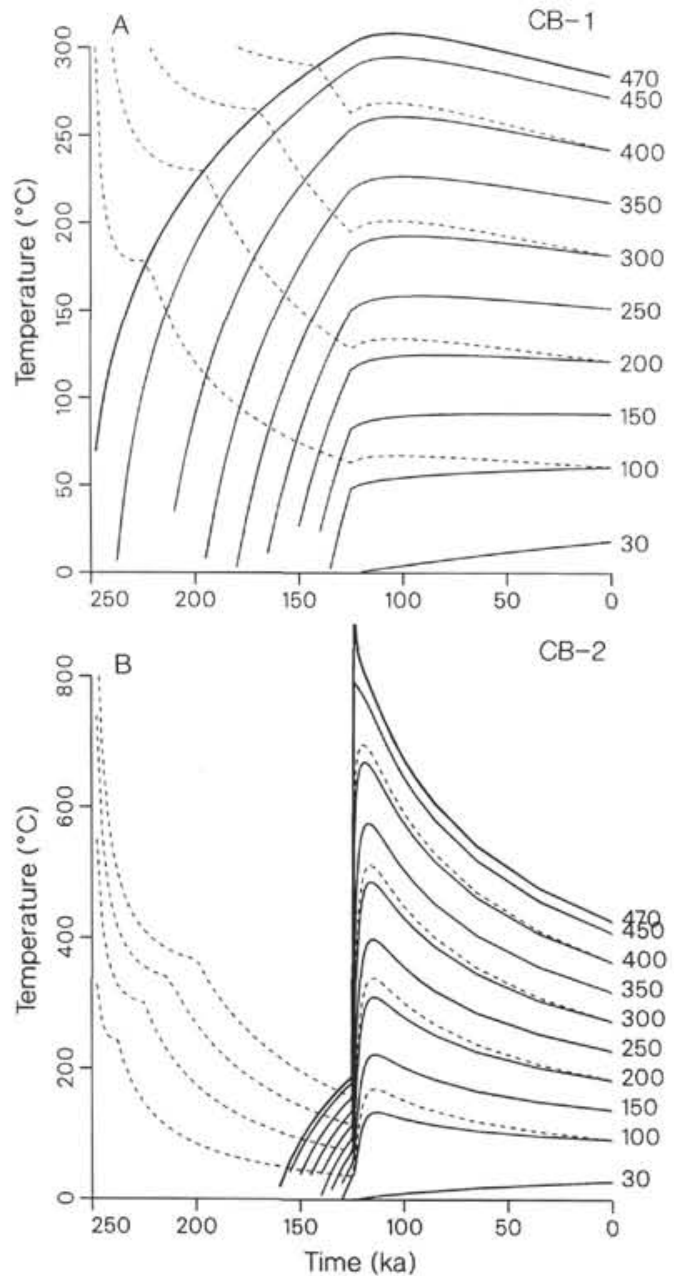

Figure 4. Results of a model simulating sedimentation on a basement layer that cools conductively from $1200^{\circ} \mathrm{C}$. Dashed lines track temperatures at fixed depths below the seafloor, and solid lines track temperatures of selected sediment elements. The number at the tail of each solid curve shows the present depth of each sediment element. In case CB-1 (A), the conductive basement that is presently at $470 \mathrm{mbsf}$ has been present since $250 \mathrm{ka}$. In case CB-2 (B), this basement was formed at $125 \mathrm{ka}$ upon the intrusion of basaltic sills (the breaks on the dashed curves prior to $125 \mathrm{kyr} \mathrm{BP}$ trace the temperature of the upper surface of the old basement).

vations of cored material. Evidence against conductive basement models in general comes from the metamorphic and hydrothermal mineralogy of the igneous rocks and interbedded sediments below $470 \mathrm{mbsf}$ which suggest that high temperatures were never sustained.

In the cases of the hydrothermal basement simulations (Fig. 5), the agreement between the model results for the present time and the estimated steady-state profile is not surprising. There is a good match because (1) the temperature and final depth of basement were specified according to the constraints offered by Figure $1 \mathrm{C}$, and (2) the efficiency of hydrothermal heat transport to the base of the sediments causes the section to be maintained at close to steady-state conditions, even in the presence of relatively high rates of sediment accumulation (Wang and Davis, 1992). The results suggest that temperatures throughout the section at Site 857 may never have been higher than they are at the present time, and that whatever the earlier, less wellconstrained history of the section may have been, temperatures have probably been close to present-day values for a period of over 100,000 yr (compare HB-1 and HB-2 in Figs. 5A and 5B, respectively).

The current situation, in which the sediment section slowly thickens and warms, will presumably continue until the supply of hot water
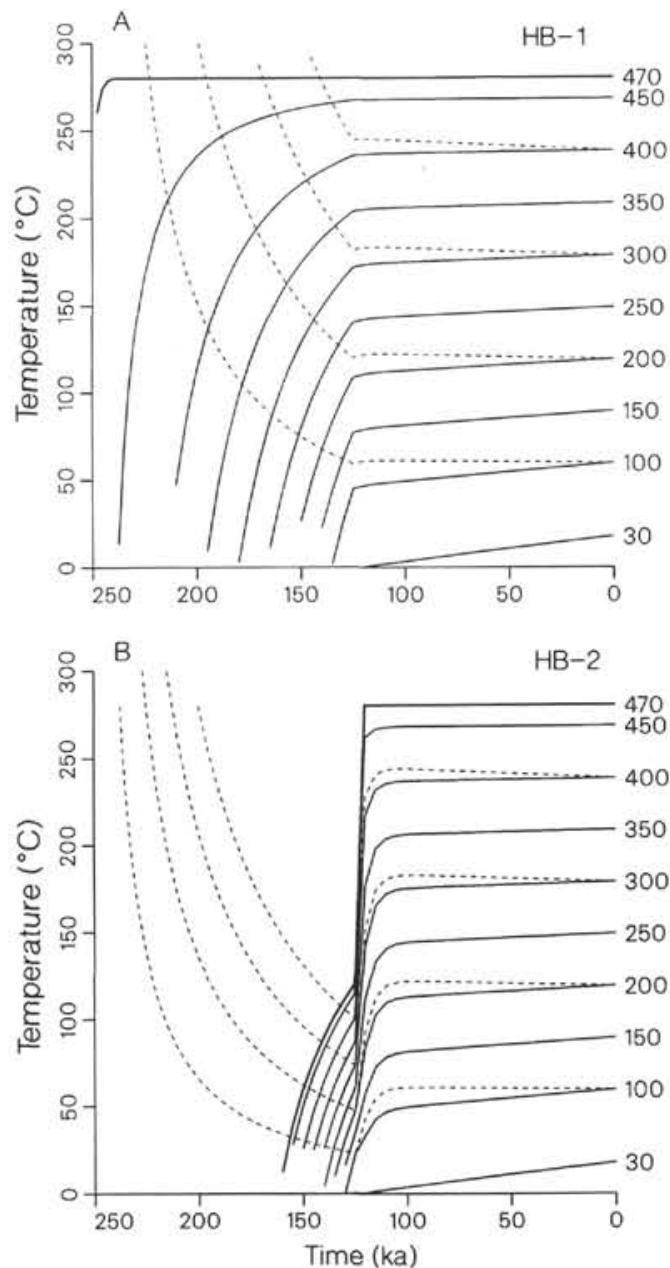

Figure 5. Results of a model simulating sedimentation on a basement layer maintained at a constant temperature by hydrothermal circulation. Conventions as in Figure 4. In case HB-1 (A), the hydrothermal basement that is presently at $470 \mathrm{mbsf}$ has been present since $250 \mathrm{ka}$. In case HB-2 (B), this basement was formed at 125 ka upon the intrusion of basaltic sills.

to the base of the section can no longer match the total of the heat lost advectively through vents and conductively through the sediment cover, or until the sediment seal is broken and more efficient local exchange of fluids between the permeable basement and the ocean is permitted. This appears to have occurred at Site 855 which was drilled adjacent to a normal fault along the eastern edge of the valley. Vertical throw on this fault has exposed basement in the foot-wall block at the seafloor. The level of thermal maturation of organic material in the sediment section exceeds that which would occur at present-day temperatures (Shipboard Scientific Party, 1992a; Whelan et al., this volume), suggesting that the sediment section has been cooled by seawater recharge along the fault.

\section{SUMMARY}

Despite efforts to determine the thermal structure deep in the section penetrated by drilling at Site 857 , accurate measurements of temperature were limited to the upper $80 \mathrm{~m}$ of the sediment column. In this paper we have estimated formation temperatures at depth by extrapolating these shallow measurements using estimates of in-situ physical properties derived from shipboard and shore-based laboratory analyses. Effects of thermal conductivity anisotropy and temperature were considered in the estimate of thermal conductivity derived from a porosity-depth profile. A temperature profile that 
reaches $280^{\circ} \mathrm{C}$ at $470 \mathrm{mbsf}$, the depth of the first sill in the section, is compatible with the constraints offered by the temperature and physical properties data. This temperature is the same as that measured at vents at Site $8581.6 \mathrm{~km}$ to the north. The coincidence is consistent with the hypothesis that the sill complex penetrated at Site 857 serves as a "hydrothermal reservoir" that supplies fluid to the remote location of discharge at Site 858, and that the overlying sediment section is of sufficiently low permeability to provide a hydrologic barrier to thermally significant pore-fluid flow.

We have also estimated the thermal history of the sediment that was deposited on top of the hydrothermal basement, with the goal of providing a context in which the alteration of the sediments can be better understood, in particular the maturation and possible migration of hydrocarbon compounds, the inorganic chemical interaction of sediments and pore fluids, the thermal diagenesis of clays and other minerals, and the isotopic composition of recrystallized minerals. The depositional history was estimated using biostratigraphic and structural age constraints. Two cases were considered, one in which sediment was deposited on a basement that cooled from initial magmatic temperature by conduction, and one in which deposition took place on a basement maintained at a constant temperature by hydrothermal circulation. All models yielded present-day temperatures within the sediment section that are virtually identical to those estimated in the first part of the paper. Conductive cooling of basement can be excluded, however, on the basis of the lack of evidence for sustained high temperatures $\left(>400^{\circ} \mathrm{C}\right)$ within or immediately above the sill complex. In the more likely case where nearly constant temperatures have been maintained in the sill complex by hydrothermal circulation, the results demonstrate that the temperature of any sediment parcel has steadily increased throughout the history of sedimentation. Because the recent sedimentation rate at this site has been relatively low, however, sediment temperatures are estimated to have been very close to present-day temperatures for the past $100,000 \mathrm{yr}$.

\section{ACKNOWLEDGMENTS}

The authors extend their thanks to $\mathrm{H}$. Villinger, with whom countless hours have been spent discussing physical properties, and $\mathrm{C}$. Brunner, who shared information and wise reservations about the biostratigraphic age constraints used in this paper. The paper benefited from comments from A. Fisher, L. Lawver, T. Lewis, and $\mathrm{H}$. Pollack. Geological Survey of Canada contribution number 47092.

\section{REFERENCES}

Brigaud, F., and Vasseur, G., 1989. Mineralogy, porosity and fluid control on thermal conductivity of sedimentary rocks. Geophys. J., 98:525-542.

Davis, E.E., Becker, K., Pettigrew, T., Carson, B., and MacDonald, R., 1992. CORK: a hydrologic seal and downhole observatory for deep-ocean boreholes. In Davis, E.E., Mottl, M.J., Fisher, A.T., et al., Proc. ODP, Init. Repts., 139: College Station, TX (Ocean Drilling Program), 43-53.

Davis, E.E., and Villinger, H., 1992. Tectonic and thermal structure of the Middle Valley sedimented rift, northern Juan de Fuca Ridge. In Davis, E.E., Mottl, M.J., Fisher, A.T., et al., Proc. ODP, Init. Repts., 139: College Station, TX (Ocean Drilling Program), 9-41.

Hutchison, I., 1985. The effect of sedimentation and compaction on oceanic heat flow. Geophys. J. R. Astron. Soc., 82:439-459.

Sengers, J.V., and Watson, J.T.R., 1987. Improved international formulations for the viscosity and thermal conductivity of water substance. J. Phys. Chem. Ref. Data, 15:1291.

Shipboard Scientific Party, 1992a. Site 855. In Davis, E.E., Mottl, M.J., Fisher, A.T., et al., Proc. ODP, Init. Repts., 139: College Station, TX (Ocean Drilling Program), 101-160.

, 1992b. Site 857. In Davis, E.E., Mottl, M.J., Fisher, A.T., et al., Proc. ODP, Init. Repts., 139: College Station, TX (Ocean Drilling Program), 283-429.

1992c. Site 858. In Davis, E.E., Mottl, M.J., Fisher, A.T., et al., Proc. ODP, Init. Repts., 139: College Station, TX (Ocean Drilling Program), 431-569.

Von Herzen, R.P., and Uyeda, S., 1963. Heat flow through the Pacific Ocean floor. J. Geophys. Res., 68:4219-4250.

Wang, K., and Davis, E.E., 1992. Thermal effects of marine sedimentation in hydrothermally active areas. Geophys. J. Int., 110:70-78.

Zoth, G., and Haenel, R., 1988. Appendix. In Haenel, R., Rybach, L., and Stegena, L. (Eds.), Handbook of Terrestrial Heat-Flow Density Determination: Dordrecht (Kluwer Academic), 449-468.

Abbreviations for names of organizations and publications in ODP reference lists follow the style given in Chemical Abstracts Service Source Index (published by American Chemical Society).

Date of initial receipt: 10 December 1992

Date of acceptance: 6 April 1993

Ms 139SR-254 